\title{
Epidemiology of malignancies in HIV patients at Kamuzu Central Hospital in Lilongwe, Malawi
}

\author{
Elizabeth Bigger ${ }^{1 *}$, Carol Shores ${ }^{2,4}$, Mina Hosseinipour ${ }^{3}$, Agnes Moses $^{1}$, Albert Mwafongo ${ }^{1}$ \\ From $12^{\text {th }}$ International Conference on Malignancies in AIDS and Other Acquired Immunodeficiencies \\ (ICMAOI) \\ Bethesda, MD, USA. 26-27 April, 2010
}

\section{Clinical background}

Malawi lacks an operational cancer registry, thus reliable epidemiological data to develop evidence-based care and focused research. HIV, infecting approximately $20 \%$ of urban Malawians [1], contributes to the pathogenesis of cancers, particularly AIDS-defining malignancies (Kaposi's sarcoma, non-Hodgkin's lymphoma, and cervical cancer) $[2,3,4$,$] . As antiretroviral use expands and life expectancy$ increases, malignancies will become a more significant cause of morbidity and mortality in this population. To gain understanding about malignancies in Malawians, we designed a database to collect clinical data for all presenting cancer patients at Kamuzu Central Hospital $(\mathrm{KCH})$ in Lilongwe, Malawi.

\section{Methods}

Patients with histologically confirmed or clinically diagnosed malignancies were identified at Kamuzu Central Hospital's departments of Medicine, General Surgery, Gynecology, Dental, Pediatrics, and Ophthalmology. From September 2009, patients underwent interviews and medical chart reviews to complete database questionnaires. Collected information included demographic data (age, sex, race, home village), family history of malignancy, exposure to potential carcinogens (tobacco, alcohol, and marijuana use, water source, cooking materials, and insecticide exposure), past medical history (including HIV, malaria, tuberculosis, and schistosomiasis), tumor location, histology diagnosis, stage, and treatment received. The questionnaire data were entered into a Web-based metaclinics database and extracted into Microsoft Excel. Calculations and analysis were performed with Excel. The cancer database will continue until at least 2013.

*Correspondence: e.bigger@gmail.com

1 Department of Medicine, UNC Project, Lilongwe, Malawi

Full list of author information is available at the end of the article

\section{Results}

Thus far, 315 cancer patients have been identified, with 152 (48.3\%) HIV positive, 36 (11.4\%) ignorant of their HIV status, and 127 (40.3\%) HIV-negative (Table 1). For representation from different departments, there were 155 patients from Medicine, 62 from Surgery, 48 from Pediatrics, 32 from Gynecology, 13 from Ophthalmology, and 5 from Dental. Of the HIV-positive patients, 107 (70.4\%) had Kaposi's sarcoma, 14 (9.2\%) had lymphoma, 13 (8.6\%) had cervical cancer, 4 (2.6\%) had breast cancer, $2(1.3 \%)$ had esophageal cancer, 2 (1.3\%) had squamous cell carcinoma of the penis, and $2(1.3 \%)$ had conjunctival squamous cell carcinoma. More HIV patients with Kaposi's sarcoma used tobacco and alcohol than HIV patients with other malignancies (Table 2). Among HIV-positive patients, 126 (82.9\%) had a history of malaria infection, and $34(22.4 \%)$ had a history of TB infection.

\section{Conclusions}

The majority of registered patients came from the Medicine Department, suggesting possible under-reporting from other departments. Almost half of the diagnosed malignancies registered occurred in known HIV-positive patients with Kaposi's sarcoma as the most common malignancy. Analysis of broader epidemiological data about malignancies of HIV patients in Malawi will aid future efforts for prevention and treatment.

\begin{tabular}{|c|c|c|c|c|}
\hline & $\begin{array}{l}\text { Total } \\
\text { Cases }\end{array}$ & $\begin{array}{l}\text { Male } \\
\text { Cases }\end{array}$ & $\begin{array}{l}\text { Current Age } \\
\text { (mean in years) }\end{array}$ & $\begin{array}{l}\text { Age Range } \\
\text { (years) }\end{array}$ \\
\hline HIV-positive & 152 & 95 & 38.5 & 6 to 77 \\
\hline HIV-negative & 127 & 67 & 40.5 & 3 to 96 \\
\hline All patients & 315 & 178 & 39.8 & 1 to 96 \\
\hline
\end{tabular}


Table 2 Distribution of malignancies, infectious disease history, and substance use of HIV patients

\begin{tabular}{lllll}
\hline & $\begin{array}{l}\text { Kaposi's } \\
\text { sarcoma }\end{array}$ & Lymphoma & $\begin{array}{l}\text { Cervical } \\
\text { Cancer }\end{array}$ & Other \\
\hline Total & 107 & 14 & 13 & 18 \\
Tobacco & 37 & 2 & 0 & 1 \\
No Alcohol & 51 & 11 & 13 & 16 \\
Light Alcohol & 12 & 0 & 0 & 1 \\
Heavy Alcohol & 44 & 3 & 0 & 1 \\
TB & 21 & 6 & 2 & 5 \\
Malaria & 92 & 8 & 12 & 14 \\
\hline
\end{tabular}

\section{Acknowledgements}

This article has been published as part of Infectious Agents and Cancer Volume 5 Supplement 1, 2010: Proceedings of the $12^{\text {th }}$ International Conference on Malignancies in AIDS and Other Acquired Immunodeficiencies (ICMAOI). The full contents of the supplement are available online at http://www.biomedcentral.com/1750-9378/5?issue=S1.

\section{Author details}

${ }^{1}$ Department of Medicine, UNC Project, Lilongwe, Malawi. ${ }^{2}$ Department of Otolaryngology, University of North Carolina at Chapel Hill, Chapel Hill, NC, USA. ${ }^{3}$ Department of Medicine, Division of Infectious Diseases, University of North Carolina at Chapel Hill, Chapel Hill, NC, USA. ${ }^{4}$ Lineberger

Comprehensive Cancer Center, University of North Carolina at Chapel Hill,

Chapel Hill, NC, USA.

Published: 11 October 2010

doi:10.1186/1750-9378-5-S1-A26

Cite this article as: Bigger et al:: Epidemiology of malignancies in HIV patients at Kamuzu Central Hospital in Lilongwe, Malawi. Infectious Agents and Cancer 2010 5(Suppl 1):A26.

Submit your next manuscript to BioMed Central and take full advantage of:

- Convenient online submission

- Thorough peer review

- No space constraints or color figure charges

- Immediate publication on acceptance

- Inclusion in PubMed, CAS, Scopus and Google Scholar

- Research which is freely available for redistribution

Submit your manuscript at www.biomedcentral.com/submit 